\title{
Peranan Tiga Pilar dalam Penyelesaian Konflik Tenurial di Taman Wisata Alam Ruteng, Flores, Nusa Tenggara Timur
}

\author{
Kriswoyo a*, Jimmy Pello a, Ludji M. Riwu Kaho a \\ ${ }^{a}$ Program Studi Ilmu Lingkungan Universitas Nusa Cendana, Kupang-Indonesia
}

*Email: tunggak_semi82@yahoo.co.id; jimmypello@yahoo.co.id; michaelrk24@gmail.com

Diterima (received) 9 September 2018; disetujui (accepted) 31 Januari 2019; tersedia secara online (available online) 1 Februari 2019

\begin{abstract}
Manggarai communities has been in and around the area of Ruteng Recreation Parksince before the establishment. The determination of the area for conservation cause tenure conflictsfor the closure region for access to agricultural and the timber. The conflict resolution involves three elements, namely the government, customs and religion are called the three pillars. This study aims to understand the stages of the conflict tenure in Manggarai, relevant stakeholders and the role of the three pillars in conflict resolution. The study was conducted in four villages with village conflicting criteria and do not conflict in April to May 2016. Acquisition of data using observation, in-depth interviews with a purposive and snowball and secondary data. Analysis of data using analysis of tree conflicts, stakeholders and conflict mapping. The results showed that the cause of the conflict which is the difference value systems which have implications for the disagreement land status and boundaries as well as the uncertainty of access due to rights issues and access. Ruteng Recreation Park area assignment is not determined by the collective perception that lack of support of the parties. Ruteng Recreation Parksetting legislation and its implementation does not guarantee the security of rights and indigenous peoples' access due to constraints of knowledge and understanding of the laws and regulations, resource constraints, regulatory and administrative development issues. The concept of the three pillars was not optimal because it has not reduced the rate of destruction of Ruteng Recreation Park and there were still conflict of encroachment and illegal logging.
\end{abstract}

Keywords: conflicts; tenure; tree pillar; Ruteng Recreation Park

\begin{abstract}
Abstrak
Masyarakat Manggarai telah berada di dalam dan sekitar kawasan Taman Wisata Alam (TWA) Ruteng sejak sebelum penetapan kawasan. Penetapan kawasan menyebabkan konflik tenurial karena tertutupnya akses pemanfaatan untuk lahan pertanian dan pemanfaatan kayu dalam kawasan. Penyelesaian konflik tersebut melibatkan tiga unsur, yaitu unsur pemerintah, adat dan agama yang disebut dengan tiga pilar. Penelitian ini bertujuan untuk memahami tahapan konflik tenurial di Manggarai, stakeholder yang terkait dan peranan tiga pilar dalam penyelesaian konflik. Penelitian dilakukan pada 4 desa dengan kriteria desa berkonflik dan tidak berkonflik pada bulan April sampai dengan Mei 2016. Perolehan data menggunakan cara observasi, wawancara mendalam dengan cara purposive dan snowball dan data sekunder. Analisis data menggunakan analisis pohon konflik, stakeholders dan pemetaan konflik. Dari hasil penelitian menunjukkan bahwa penyebab konflik yaitu perbedaan sistem nilai yang berimplikasi pada ketidaksepakatan status lahan dan tata batas serta ketidakpastian akses karena persoalan hak dan akses. Penunjukan kawasan TWA Ruteng tidak ditentukan dengan persepsi kolektif sehingga kurang mendapat dukungan para pihak. Peraturan perundangan penetapan TWA dan implementasinya tidak menjamin kepastian hak dan akses masyarakat adat karena kendala pengetahuan dan pemahaman mengenai peraturan perundangan, keterbatasan sumberdaya, persoalan administrasi dan birokrasi pembangunan. Konsep tiga pilar belum optimal karena belum mengurangi laju kerusakan TWA Ruteng dengan masih adanya konflik seperti perambahan dan illegal logging.
\end{abstract}

Kata Kunci: konflik; tenurial; tiga pilar; taman wisata alam

doi: https://doi.org/10.24843/blje.2019.v19.i01.p05

(C) 2019 by the authors; Content from this work may be used under the terms of the Creative Commons Attribution 3.0 licence. Any further distribution of this work must maintain attribution to the author(s) and the title of the work, journal citation and DOI. Published under licence by Udayana University, Indonesia. 


\section{Pendahuluan}

Penetapan kawasan konservasi merupakan salah satu langkah pemerintah dalam menangani persoalan degradasi keanekaragaman hayati. Dari luas kawasan konservasi sebesar 27.1 juta Ha yang terdapat di Indonesia, 2,8\% diantaranya ialah taman wisata alam. Namun penetapan dan pengelolaan kawasan konservasi di Indonesia kurang mempertimbangkan keberadaan masyarakat dengan kearifan lokalnya di dalam dan sekitar kawasan (Damayanti 2008). Pengelola kawasan konservasi menutup akses masyarakat adat dalam pemanfaatan sumberdaya tumbuhan hutan karena dianggap sebagai sumber kegagalan konservasi hutan (Bahruni, dik., 2007; Kartodihardjo 2013).

Hutan menurut Ostrom (1990) merupakan common pool resources (CPRs), yaitu sistem sumberdaya alam atau buatan yang cukup besar sehingga biaya untuk membatasi atau melarang pihak-pihak yang berpotensi memanfaatkan sumberdaya terlalu tinggi sehingga sulit dalam pelaksanaannya. Penutupan hutan terhadap pemanfaatan oleh masyarakat adat menurut Hardin (1968) akan cenderung mengakibatkan open access sehingga sumberdaya tidak terawasi dengan baik karena tidak ada pengaturan sehingga berakibat dapat terjadi pengurasan sumberdaya. Penutupan akses masyarakat menyebabkan kurangnya pemahaman bersama dalam pengelolaan kawasan.

Salah satu konflik penutupan akses terhadap kawasan konservasi tersebut terjadi di Taman Wisata Alam (TWA) Ruteng yang disebabkan oleh pemanfaatan lahan hutan dalam kawasan dan penebangan kayu oleh masyarakat sekitar kawasan. Perambahan lahan disebabkan oleh tingkat kesuburan lahan kawasan yang lebih baik sedangkan penebangan liar disebabkan belum mencukupinya kebutuhan kayu oleh pasokan dari kebun masyarakat dan belum adanya pasokan kayu dari luar daerah.

Perambahan hutan terjadi pada sepanjang lingkar batas TWA Ruteng yang umumnya ditanami kopi. Permasalahan pengelolaan Hutan Ruteng menjadi semakin kompleks dengan meninggalnya 6 orang dan 26 orang terluka parah akibat konflik dengan polisi dan petugas kehutanan (Iswandono et al., 2015). Pengelolaan hutan itu seharusnya bukan untuk membatasi akses masyarakat dalam memanfaatkan hutan, karena ada skema pemanfaatan hutan bersama masyarakat melalui penataan kawasan hutan.

Sejak peristiwa berdarah tersebut, tidak pernah terjadi komunikasi antara Balai Besar KSDA NTT dengan masyarakat Adat Colol. Upaya-upaya yang dilakukan secara sistematis baru dimulai pada bulan Oktober 2012. Balai Besar KSDA NTT mempelopori konsep Tiga Pilar yang melibatkan unsur pemerintah, adat dan agama sebagai Gerakan Bersama Menyelamatkan TWA Ruteng dengan membuka ruang negosiasi untuk inisiasi pola pemanfaatan potensi sumber daya alam hayati secara lestari dengan harapan konflik kepentingan dengan masyarakat adat dapat diselesaikan secara damai untuk menuju hutan lestari rakyat sejahtera. Untuk itulah diperlukan analisis konflik untuk memahami tahapan konflik tenurial di Manggarai, stakeholder yang terkait dan peranan tiga pilar dalam penyelesaian konflik.

\section{Metode Penelitian}

Penelitian ini dilakukan selama 2 bulan mulai April sampai dengan Mei 2016 pada wilayah TWA Ruteng. Lokasi sampel berada pada 4 desa di sekitar kawasan dengan kriteria desa yang berkonflik, yaitu: Kelurahan Waso dan Desa Colol dan desa yang tidak berkonflik, yaitu Desa Pongkor dan Kelurahan Lempang Paji (Gambar 1).

Perolehan data penelitian menggunakan cara observasi, wawancara mendalam dan data sekunder dari laporan instansi, literatur penting, peraturan perundang-undangan dan data pendukung lainnya. Untuk menguji kevalidan atau keabsahan data maka dilakukan teknik triangulasi, yaitu menggabungkan berbagai data yang diperoleh dari berbagai teknik pengumpulan dan sumber data serta melakukan cross check data untuk menguji kredibilitas data. Wawancara mendalam dengan menetapkan informan berdasarkan status dan perannya dalam masyarakat berdasarkan kecukupan informasi dengan cara purposive dan snowball (Sugiyono 2010). Penentuan informan secara sengaja (purposive) yang memiliki pemahaman mengenai konflik pemanfaatan di dalam kawasan TWA Ruteng. Sumber data berdasarkan petunjuk awal informan yang merekomendasikan informan lainnya (snowball), yang mengerti permasalahan pemanfaatan lahan dan spesies dalam kawasan TWA Ruteng. 


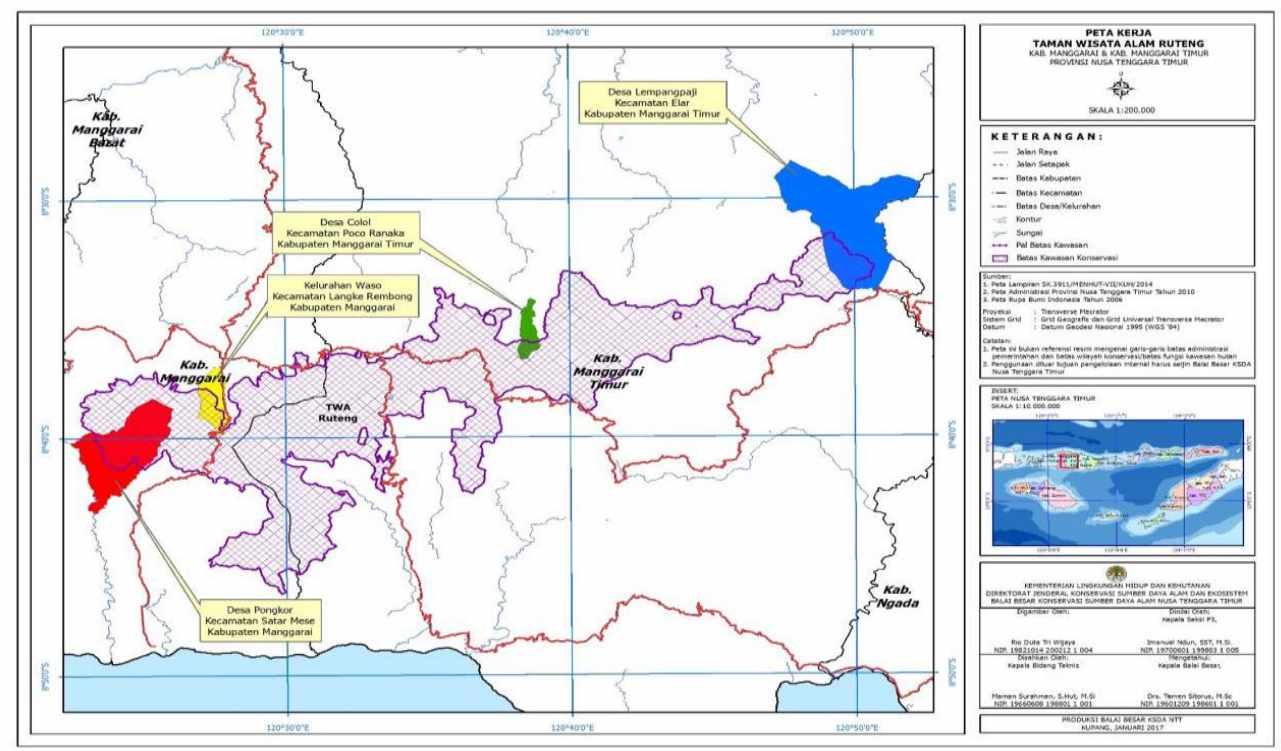

Gambar 1. Lokasi Studi Penelitian

Analisis data menggunakan 3 analisis konflik yaitu 1) analisis pohon konflik untuk mengurutkan isu-isu pokok konflik, menganalisis masalah inti, penyebab awal/ akar masalah dan efek-efek yang muncul sebagai akibat masalah tersebut serta isu-isu penting yang perlu mendapat perhatian khusus; Analisis stakeholders adalah untuk untuk mengidentifikasi individu atau organisasi yang terkait dengan persoalan pengurusan hutan di TWA Ruteng. Hasil dari analisis ini adalah daftar stakeholder yang terkait berikut kategorinya, hubungan antar stakeholder dan pengaruhnya terhadap proses penetapan TWA Ruteng. Selanjutnya analisis pemetaan konflik, digunakan untuk menggambarkan konflik secara grafis, menghubungkan pihak-pihak dengan masalah dan dengan pihak lainnya. Setelah menguraikan penggunaan 3 (tiga) alat bantu analisis konflik diatas, penulis mencoba menerapkan hasil-hasil yang diperoleh melalui penggunaan alat-alat bantu analisis tersebut dalam tahapan siklus konflik sehingga dapat memahami tahap konflik perambahan kawasaan TWA Ruteng (Kriesberg, 2012).

\section{Hasil}

\subsection{Sejarah Pengelolaan Kawasan Taman Wisata Alam Ruteng}

Hutan Ruteng pada awalnya berstatus hutan lindung seluas 17857.60 hektar dan hutan produksi terbatas seluas 14388 hektar yang saat ini berada di wilayah Kabupaten Manggarai dan Manggarai Timur. Potensi kekayaan spesies terutama jenis burung, fungsi hidrologi untuk kota Ruteng dan Borong serta wisata alam pegunungan hutan hujan tropis yang menarik dan mudah diakses oleh wisatawan menjadi dasar penetapan kawasan Hutan Ruteng seluas 32248.60 hektar menjadi Taman Wisata Alam dengan Surat Keputusan Menteri Kehutanan Nomor: 456/Kpts-II/1993 tanggal 24 Agustus 1993. Kawasan sudah memiliki tata batas dan sudah ketemu gelang sehingga dapat dilakukan pengelolaan secara legal formal. TWA Ruteng saat ini berada di bawah pengelolaan Balai Besar Konservasi Sumber Daya Alam Nusa Tenggara Timur yang berkedudukan di Kupang.

Pengelolaan TWA Ruteng sejak tahun 1993 pertama kalinya dilakukan pemerintah melalui Proyek Konservasi Alam Terpadu (PKAT) yang merupakan salah satu dari dua bagian proyek yaitu Taman Wisata Alam Ruteng dan Taman Nasional Siberut. Proyek tersebut merupakan pinjaman lunak (soft loan) dari Asian Development Bank (ADB), namun proyek ini dihentikan setelah 6 tahun berjalan pada tahun 1999 dari rencana programnya selama 20 tahun (Trainor dan Lesmana 2000; Darmanto 2011). Proyek 
PKAT adalah bagian dari skema Integrated Conservation and Development Project yang diterapkan di seluruh dunia. Proyek ini menyelaraskan kepentingan pelestarian alam dengan kepentingan masyarakat tradisional yang ada di dalam dan sekitar kawasan hutan terutama untuk pengembangan ekonomi masyarakat tradisional (Wells et al. 1992).

Tabel 1. Sejarah Pengelolaan Kawasan Hutan Ruteng

\begin{tabular}{|c|c|c|c|}
\hline Tahun & Pengelola Kawasan & $\begin{array}{c}\text { Nomor SK Menteri } \\
\text { Kehutanan }\end{array}$ & $\begin{array}{c}\text { Kedudukan, Jumlah } \\
\text { Kawasan dikelola }\end{array}$ \\
\hline Sebelum 1993 & Dinas Kehutanan Manggarai & - & Ruteng \\
\hline $1993-1999$ & BPPKAT & - & Ruteng, 1 kawasan \\
\hline $1999-2002$ & Unit KSDA NTT II & $\begin{array}{l}\text { 204/Kpts-II/1998, } \\
27 \text { Pebruari } 1998\end{array}$ & Ruteng, 15 kawasan \\
\hline $2002-2007$ & Balai KSDA NTT II & $\begin{array}{l}\text { 6187/Kpts-II/2002, } \\
10 \text { Juni } 2002\end{array}$ & Ruteng, 15 kawasan \\
\hline $2007-2014$ & Balai Besar KSDA NTT & $\begin{array}{l}\text { P.02/Menhut-II/2007, } \\
1 \text { Pebruari } 2007\end{array}$ & Kupang, 28 Kawasan \\
\hline 2014 - saat ini & KPHK Ruteng & $\begin{array}{l}\text { SK.986/Menhut-II/2013, } \\
27 \text { Desember } 2013\end{array}$ & Ruteng, 1 kawasan \\
\hline
\end{tabular}

Pada tahun 1999, pengelolaan Hutan Ruteng diserahkan kepada Unit Pelaksana Teknis (UPT) Balai Konservasi Sumber Daya Alam di bawah Kementerian Kehutanan. Struktur organisasi pengelola mengalami perubahan sebanyak beberapa kali (Tabel 1), sampai saat ini dikelola oleh satu unit tersendiri yaitu Kesatuan Pengelolaan Hutan Konservasi (KPHK) Ruteng. Data konflik pada wilayah desa sampel di lokasi penelitian selengkapnya seperti pada Tabel 2.

Tabel 2. Data konflik tenurial pada wilayah studi di TWA Ruteng

\begin{tabular}{|c|c|c|}
\hline Wilayah Studi & Penyebab Konflik & Jenis Konflik \\
\hline Desa Colol & Klaim tanah Adat & Konflik Terbuka \\
\hline $\begin{array}{l}\text { Kelurahan Lempang } \\
\text { Paji }\end{array}$ & $\begin{array}{l}\text { Belum dapat memanfaatkan air dalam kawasan } \\
\text { TWA Ruteng karena terhalang aturan }\end{array}$ & Konflik Laten \\
\hline Kelurahan Waso & Perambahan dan illegal logging & Konflik Terbuka \\
\hline Desa Pongkor & $\begin{array}{l}\text { Kuburan nenek moyang di dalam kawasan TWA } \\
\text { Ruteng }\end{array}$ & Konflik Laten \\
\hline
\end{tabular}

\subsection{Analisis Konflik}

Dari analisis pohon konflik diketahui bahwa penyebab konflik tenurial adalah motivasi ekonomi, yuridis, sosiologis, tingkat pendidikan dan kesadaran masyarakat yang rendah serta motivasi historis/budaya. Data selengkapnya seperti pada Gambar 2.

Pihak-pihak utama dalam konflik ini adalah Balai Besar KSDA NTT selaku pengelola kawasan TWA Ruteng dengan masyarakat sekitar kawasan TWA Ruteng (Gambar 3). Pihak-pihak lain yang terlibat adalah:

- Pemerintah Kabupaten Manggarai dan Manggarai Timur yang memiliki wilayah administrasi.

- Pemerintah Pusat (Kementerian Lingkungan Hidup dan Kehutanan), karena urusan konservasi menjadi tanggungjawab pemerintah pusat

- Masyarakat Adat sekitar kawasan TWA Ruteng karena berdasarkan sejarah sosial budaya masyarakatmasyarakat berada di dalam dan sekitar TWA Ruteng. 
- Gereja Katolik (Uskup Ruteng) karena merupakan institusi dengan kultur yang kuat terhadap masyarakat sekitar kawasan TWA Ruteng dan memiliki peran strategis dalam mempengaruhi setiap pandangan umat Katolik.

- LSM (Mitra Kita, Garuda, PBH Nusra, persatuan bantuan hukum Nusa Tenggara, Aman, dll) karena memiliki aliansi dengan masyarakat dalam bentuk advokasi, pendampingan, repatriasi dsb.

- DPRD, POLRES Manggarai dan KODIM 1612 karena memiliki hubugan yang timbal balik dengan Pemerintah Provinsi (Pemprov) NTT, Pemerintah Kabupaten Manggarai, Manggarai Timur, Balai Besar KSDA NTT dan masyarakat sekitar kawasan TWA Ruteng karena terjadi konflik langsung (POLRES Manggarai dan KODIM 1612) sedangkan DPRD karena kurang berkontribusi dalam peranannya sebagai wakil rakyat.

- Pihak luar yang tidak nampak namun memiliki pengaruh positif maupun negatif dalam konflik ini, adalah pihak-pihak yang perlu di identifikasi guna mengetahui perannya dalam konflik yang terjadi

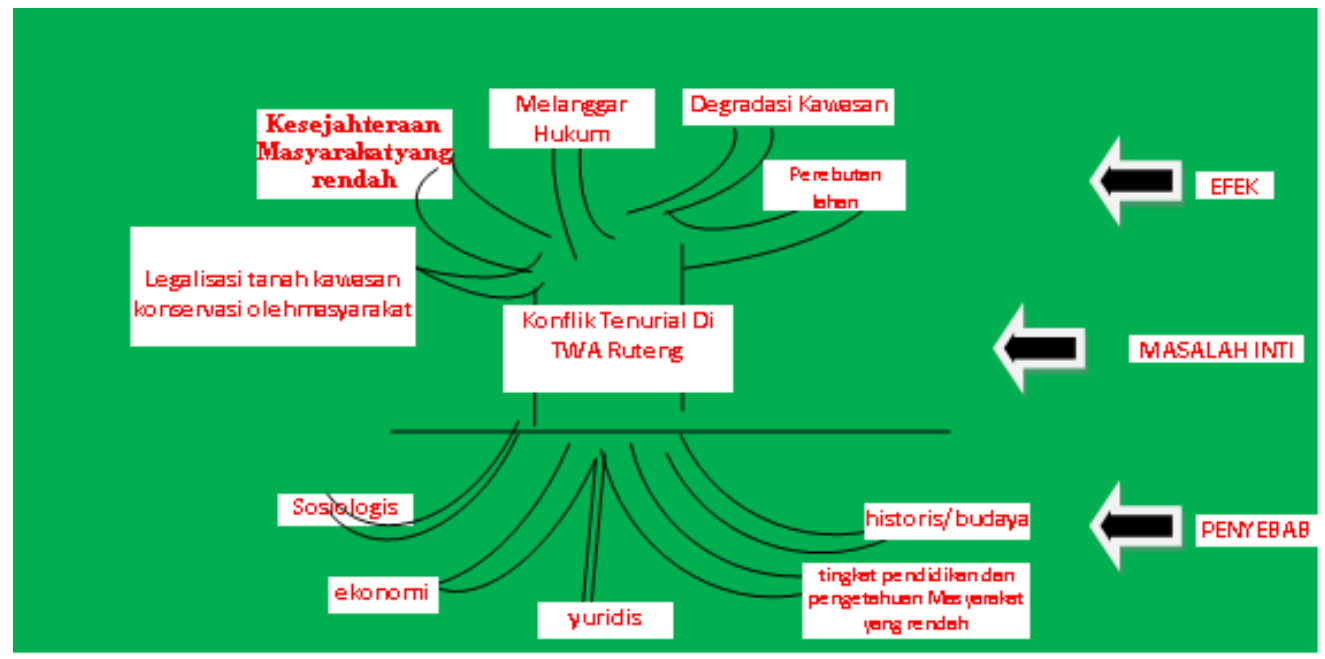

Gambar 2. Analisis pohon konflik

Pihak lain yang teridentifikasi dapat memberikan pengaruh positif adalah aparatur desa dan tokohtokoh adat yang peduli terhadap kelestarian lingkungan hidup dan tokoh muda yang berpendidikan tinggi yang peduli dan memberikan pengetahuan serta pemahaman tentang pelestarian lingkungan hidup untuk generasi mendatang. Geo politk dapat dikatagorikan positif dan negatif tergantung kepentingan politikusnya. Pihak yang teridentifikasi memberikan pengaruh negatif adalah para tengkulak atau pengepul kopi dari kota yang ikut andil dalam memprovokasi masyarakat perambah untuk mempertahankan lahan kopi garapannya. Masyarakat adat pada lokasi studi merupakan stakeholders utama karena merupakan stakeholders yang terkena dampak langsung baik positif maupun negatif oleh suatu rencana atau proyek serta mempunyai kaitan kepentingan langsung dengan kegiatan tersebut.

Konflik tenurial kebun kopi dalam kawasan perlu penelitian sejarah keberadaannya, yaitu: 1) keberadaan kebun kopi dalam kawasan sebelum atau sesudah penetapan TWA Ruteng dan 2) keberadaan kebun kopi karena proses pembiaran petugas lapangan dan tidak ada arahan serta sosialisasi. Penyelesaian permasalahan konflik tenurial tersebut memerlukan peran tiga pilar sebagai berikut:

1. Pilar Pertama : Pemerintah

Pemerintah pusat adalah Balai Besar KSDA NTT sedangkan Pemerintah daerah adalah pemerintah kabupaten, kecamatan dan desa. Kawasan TWA Ruteng, termasuk ke dalam wilayah administrasi Kab.Manggarai seluas 8.000 Ha dan di wilayah administrasi Kab.Manggarai Timur, seluas 24.235 Ha. Kawasan tersebut berbatasan dengan 76 desa dalam 6 kecamatan. Berbagai intervensi pembangunan akan berpengaruh menguntungkan atau merugikan yang berdampak pada perubahan kondisi sosial, ekonomi, budaya ke 76 desa yang secara tidak langsung berpengaruh langsung pada kelestarian TWA Ruteng. 


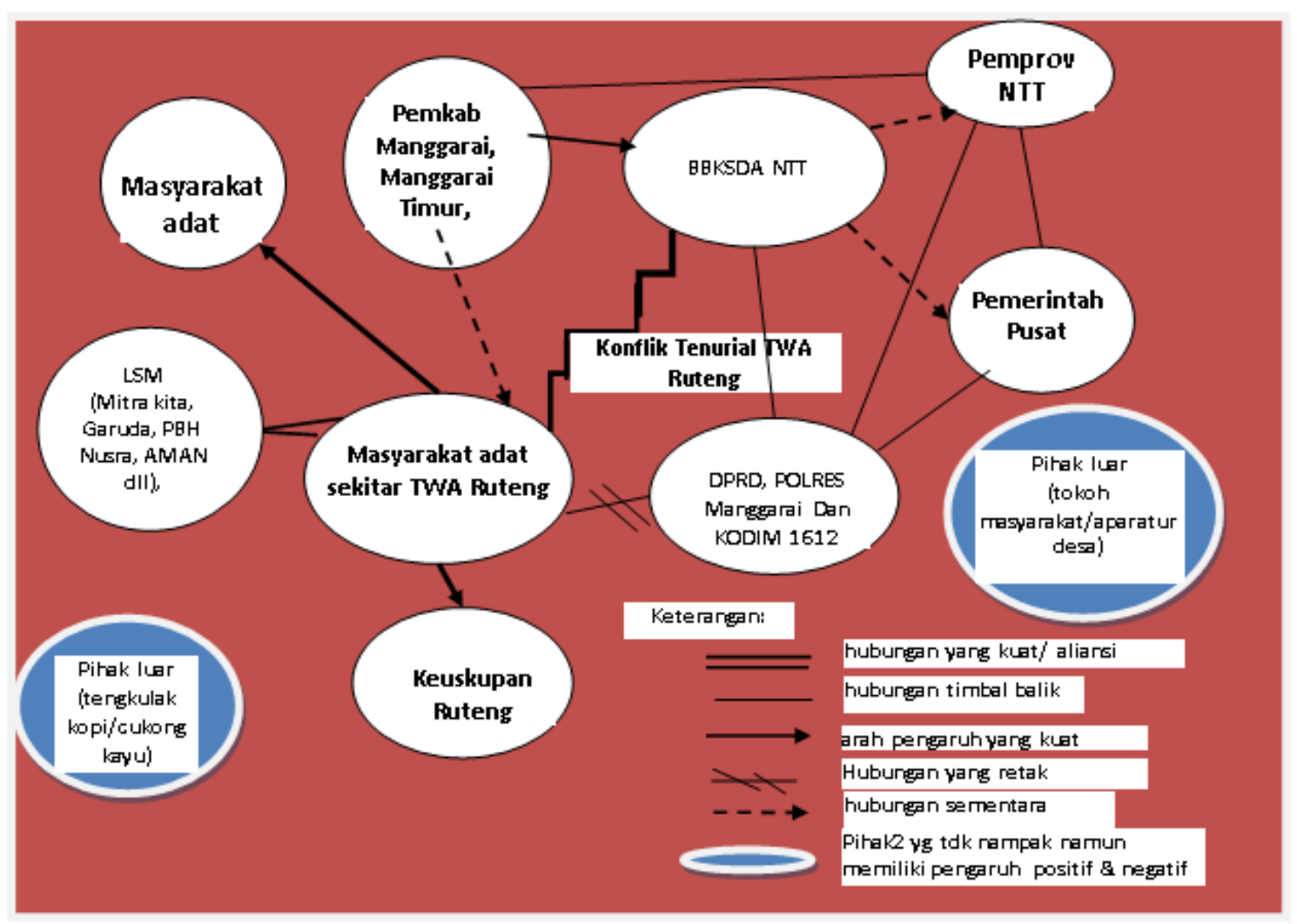

Gambar 3. Pemetaan Konflik Taman Wisata Alam (TWA) Ruteng

2. Pilar Kedua : Gereja

Di sekitar TWA Ruteng ini, terdapat 24 Paroki yang melayani 76 desa daerah penyangga. Keberadaan Gereja Kristen Katholik di Manggarai Raya berusia 100 tahun, cukup lama dan berakar di masyarakat. Dimuatnya berita Ibadat Ekologis dalam rangka Yubelium Gereja Manggarai, di Kompas (1 Maret 3012), dalam rubrik : "Menjaga Nusantara", merupakan bukti gerakan dari 3 elemen kunci di NTT, yaitu Gereja, Adat, Pemerintah setempat, telah mulai menyebar, difahami, diakui, dan dijadikan pemberitaan secara nasional. Peranan media massa dalam mendorong kesadaran kolektif, terbukti sangat vital, termasuk di dalamnya membangun keadaban publik untuk kemaslahatan kemanusiaan dengan nilainilai universalnya.

3. Pilar Ketiga : Adat

Masyarakat Manggarai masih mempertahankan struktur dan keberadaan Lembaga Adatnya. Para tetua adat dalam struktur adat Manggarai, mulai dari yang tertinggi sampai yang terendah masih berperan dalam penyelesaian masalah sosial kehutanan.

Sejak Tahun 2013 telah diadakan sebanyak 3 kali musyawarah besar tiga pilar yang bertempat di:

- Rumah Gendang Desa Colol pada tanggal 12 Desember 2012

- Kisol - Borong - Manggarai Timur pada tanggal 29 - 30 Mei 2016

- Ruteng - Kabupaten Manggarai pada tanggal 18-19 Juni 2013.

\section{Pembahasan}

\subsection{Konflik Tenurial di TWA Ruteng}

Penyebab konflik tenurial di TWA Ruteng adalah tidak adanya kesamaan konsep mengenai tapal batas, berawal dari penetapan kawasan hutan secara sepihak oleh pemerintah tanpa melibatkan 
masyarakat. Perambahan dan perusakan hutan menjadi isu utama karena masyarakat menganggap bahwa lingko adalah hak yang sudah dikuasai turun temurun, walaupun sudah ditetapkan sebagai hutan lindung maupun hutan konservasi. Pada wilayah masyarakat adat Colol, perambahan hutan merupakan persoalan lama sejak zaman Pemerintahan Belanda dan berlanjut di era kemerdekaan. Persoalan tersebut tidak diselesaikan secara arif dengan menelaah secara bersama-sama, baik secara hukum positif maupun secara hukum adat.

Konflik yang sudah sampai pada konflik terbuka terjadi pada wilayah sampel di Desa Colol dan Kelurahan Waso. Penyebab konflik terbuka adalah karena adanya pemanfaatan lahan kawasan untuk kegiatan pertanian dan illegal logging. Pada Tahun 2004 Pemerintah daerah Kabupaten Manggarai melakukan penertiban dan pengamanan hutan dengan melakukan pembabatan dan pemusnahan tanaman masyarakat adat dalam kawasan hutan. Konflik mencapai puncaknya pada 10 Maret 2004, terkenal dengan sebutan "Rabu Berdarah". Sebanyak 6 petani meninggal dan puluhan petani cacat akibat bentrokan di Polres Manggarai. Persoalan pokok dari konflik tersebut adalah dilakukannya operasi penebangan tanaman-tanaman kopi milik masyarakat Adat Colol, yang dinilai oleh Pemkab Manggarai dan Balai KSDA NTT II, telah masuk ke dalam kawasan TWA Ruteng.

Penyebab konflik dalam kawasan TWA Ruteng meliputi 4 faktor. Faktor pertama adalah perbedaan sistem nilai antara masyarakat dan pengelola kawasan hutan. Bagi masyarakat relasi mereka dengan hutan merupakan relasi yang bersifat sosial, ekonomi dan spiritual. Hutan tidak hanya berfungsi untuk memenuhi kebutuhan dasar namun melakukan aktivitas sosial budaya dan ritual kepercayaan. Hutan dipandang sebagai milik bersama (commongoods). Semua anggota masyarakat mempunyai hak untuk mengakses SDA dan kewajiban yang sama untuk melestarikannya sesuai aturan adat. Akses terhadap hutan bukan barang yang dapat diperdagangkan (common property) dan pelestarian hutan merupakan bagian dari praktek kehidupan sosial budaya (Pratiwi, 2008). Bagi pengelola,TWA Ruteng memiliki fungsi utama sebagai fungsi ekowisata dan fungsi ekologi.

Faktor kedua adalah ketidakpastian status lahan karena penetapan sepihak kawasan TWA Ruteng sehingga masuknya beberapa wilayah adat masyarakat kedalam wilayah TWA Ruteng. Dasar klaim pemerintah atas wilayah adat adalah kebijakan agraria yang menyebutkan bahwa lahan yang kepemilikannya tidak dapat dibuktikan oleh yang menguasainya menjadi domain negara (Harsono 2005:44-46). Pada Undang-Undang Kehutanan No. 41/1999 mengenai Kehutanan Pasal 67 menyebutkan bahwa pengelolaan hutan adat diakui keberadaannya namun hak tersebut dapat diberikan jika ada pengakuan dari Pemerintah Daerah (PEMDA). Asumsi hukum pemerintah bertentangan dengan kesadaran hukum yang dimengerti masyarakat. Wilayah adat bagi mereka adalah common property atau lahan milik bersama. Status tersebut ditetapkan berdasarkan kesepakatan kolektif anggota masyarakatnya (resource tenure). Status masyarakat adat yang tinggal di dalam kawasan TWA Ruteng ini menjadi encroachment atau pemukim liar. Status yang menurut masyarakat lokal sangat diskriminatif dan berimplikasi pada kurangnya tingkat kepercayaan masyarakat terhadap pemerintah.

Faktor ketiga adalah ketidaksepakatan tata batas yang disebabkan karena batas pal Belanda da pal Indonesia tidak berimpit sehingga sebagian lahan masyarakat adat berada di dalam kawasan TWA Ruteng. Pelaksanaan rekonstruksi batas kawasan di TWA Ruteng kurang melibatkan masyarakat setempat secara partisipatif sehingga menjadi salah satu penyebab konflik (Tukan et al. 1999). Faktor terakhir adalah ketidakpastian akses masyarakat terhadap sumberdaya alam di kawasan TWA Ruteng yang disebabkan oleh adanya perbedaan pandangan dan aturan pemanfaatan dengan kearifan lokal masyarakat setempat (Iswandono, 2016; Iswandono et al. 2017)

\subsection{Peranan Tiga Pilar dalam Penyelesaian Konflik}

Kegiatan perambahan kawasan hutan TWA Ruteng terbagi menjadi beberapa motivasi. Tipe motivasi karena aspek ekonomi didorong oleh kepemilikan lahan semakin sempit karena pertambahan penduduk yang significant dan lahan garapan kurang subur sedangkan lahan dalam kawasan TWA Ruteng tingkat kesuburannya lebih tinggi. Motivasi yuridis karena secara de jure peraturan perundangan menjadi satu-satunya acuan pengelolaan SDA tetapi secara de facto ada sistem nilai adat. Masyarakat tradisional di dalam dan sekitar kawasan sejak ratusan tahun sebelum penetapan kawasan memiliki hak- 
hak adat atas sumberdaya alam dengan pranata sosialnya. Secara sosiologis adalah bahwa masyarakat melakukan perambahan karena meniru masyarakat lain yang merambah hutan sejak tahun 1990-an dan diawal tahun 2000-an dan sudah memberikan dampak ekonomi keluarga yang cukup baik karena tidak memiliki keterampilan lain selain berladang yang juga ditunjang oleh rata-rata tingkat pendidikan masyarakat sekitar kawasan yang rendah. Yang terakhir adalah motivasi historis/budaya adalah bahwa masyarakat telah memanfaatkan hutan secara turun temurun yang dapat dibuktikan dengan adanya kampung lama (bangka) yang ada di dalam kawasan hutan. Hal ini pula yang mendasari masyarakat menggarap kebun pada batas kawasan dan menganggapnya sebagai budaya setempat dengan semboyan "harat kope" artinya upah menjaga batas kawasan.

Dampak utama penunjukan kawasan TWA Ruteng bagi masyarakat adat ialah terjadinya perubahan status lahan garapan. Perubahan status ini merubah tatanan kelembagaan dan aturan main pengelolaan ditingkat lokal/komunitas menjadi nasional, padahal lahan merupakan sumber kehidupan untuk kebutuhan primer. Masyarakat menganggap lahan merupakan mandat leluhur yang harus dijaga secara turun temurun jauh sebelum Indonesia merdeka. Namun demikian, beberapa keterbatasan teknis masyarakat untuk berdialog dan bernegosiasi dengan pihak yang berkepentingan seperti bahasa, tingkat pendidikan, kesamaan data dan informasi serta hal teknis lainnya menyebabkan posisi tawar mereka menjadi rendah. Bagi kelompok masyarakat yang sudah banyak berinteraksi dengan masyarakat luar dan mendapat dukungan seperti Kelurahan Waso, posisi tawar mereka untuk mempengaruhi proses penetapan kawasan menjadi cukup kuat.

Stakeholders kunci yang merupakan stakeholders yang memiliki kewenangan legal dalam hal pengambilan keputusan (Maryono et al. 2005) adalah Balai Besar KSDA NTT. Dalam penelitian ini, stakeholders kunci diidentifikasi berdasarkan kewenangannya dalam mengambil keputusan terkait dengan proses penetapan kawasan taman wisata alam. Menurut UU No. 41/1999 tentang Kehutanan Pasal 10, proses penetapan kawasan atau pengukuhan kawasan terdiri dari empat tahapan yaitu tahap penunjukan, penataan batas, pemetaan, dan penetapan. Tahap penunjukan dapat dilakukan setelah selesainya kegiatan inventarisasi kawasan. Pengurusan TWA Ruteng berada di Pemerintah Pusat, Cq. Kementerian Kehutanan. Sedangkan Balai Besar Konservasi Sumber Daya Alam NTT merupakan Unit Pelaksana Teknis (UPT) dari Kementerian Kehutanan. Namun secara administratif TWA Ruteng masuk ke dalam wilayah 2 kabupaten yaitu Kabupaten Manggarai dan Manggarai Timur. Karena itu, konflik yang berkaitan dengan kesejahteraan masyarakat seperti lahan, tata batas dan akses terhadap SDA menjadi tanggung jawab dan kewenangan pemerintah daerah.

Keterlibatan masing-masing pihak terhadap pengelolaan TWA Ruteng dipengaruhi oleh kepentingan dari masing-masing pihak. Namun kepentingan tersebut harus terlebih dahulu dimusyawarahkan dan disepakati melalui tiga pilar, yaitu unsur pemerintah, adat dan gereja di rumah gendang. Hubungan para pihak akan tercermin dan terjalin dari berbagai upaya membangun komunikasi, koordinasi, lobi, hingga kerjasama program yang akan dijalankan. Secara umum, pola hubungan antar para pihak harus terjalin secara bersama-sama melalui konsep tiga pilar yaitu pemerintah, agama dan masyarakat/adat. Kontribusi program, konsep, ataupun kebijakan, harus selalu dibicarakan secara bersama di rumah gendang.

Berdasarkan hasil analisis, konflik dalam pengurusan hutan TWA Ruteng disebabkan:

- Konflik antara masyarakat dengan BBKSDA NTT karena ketidaksepakatan masalah status dan akses terhadap lahan. Hal ini dipicu oleh klaim BBKSDA NTT dengan menetapkan peraturan dan perundangan yang dianggap sepihak dan membuat pemetaan kawasan tanpa melakukan verifikasi lapangan;

- Kurang optimalnya komunikasi antara masyarakat dengan Pemerintah Daerah selaku stakeholders kunci dan pasifnya peran PEMDA dalam menyikapi persoalan di lapangan menyebabkan masyarakat berkonfrontasi langsung dengan BBKSDA NTT. Situasi ini diperuncing oleh peran beberapa LSM yang tidak netral atau tidak jelas posisinya dalam membantu penyelesaian konflik sehingga komunikasi para pihak semakin tidak kondusif;

- Kurang optimalnya koordinasi yang dilakukan BBKSDA NTT dengan stakeholders kunci lainnya. Komunikasi dan koordinasi yang sudah ada selama ini baru sebatas saling berbagi pandangan dalam forum diskusi, seminar, konsultasi publik atau lokakarya yang diselenggarakan BBKSDA NTT. 
Pemerintah Daerah Kabupaten dan Provinsi bersikap pasif tidak proaktif dalam melakukan komunikasi dan koordinasi yang menyebabkan banyaknya persoalan di lapangan yang tidak terselesaikan dan menimbulkan ketidakpastian bagi masyarakat;

- Secara struktural dan legal formal, pemerintah kabupaten, provinsi, DPRD dan pemerintah pusat memiliki hubungan kerjasama namun tidak diperoleh informasi kerjasama dan koordinasi untuk isu konflik dalam pengurusan TWA Ruteng.

Posisi BBKSDA NTT adalah pengelola kawasan yang memiliki otoritas dan yuridiksi dalam menegakkan peraturan kehutanan. Kewenangan ini untuk menunjukan penguasaan negara atas sumbersumber daya yang menguasai hajat hidup orang banyak karena apabila dikuasai perorangan atau kelompok memiliki dampak terhadap kepentingan umum yang lebih besar. Masyarakat melakukan perambahan dan perusakan hutan karena menganggap bahwa lahan yang dijadikan lingko adalah hak turun temurun, walaupun sudah ditetapkan sebagai hutan lindung atau hutan konservasi.

Kebutuhan pengelola kawasan adalah kawasan berfungsi sesuai peruntukannya sebagaimana disebutkan dalam Peraturan Pemerintah Nomor 28 Tahun 2011 tentang KSA dan KPA sedangkan masyarakat melakukan perambahan dan Illegal loging karena untuk mencukupi kebutuhan ekonomi. Masyarakat berharap akan mendapat penghasilan lebih dengan melakukan pembalakan kayu hutan alam dan menjual pada penadah (cukong kayu). Tindakan pembalakan kayu illegal dapat dikatagorikan sebagai tindakan rasional instrumental karena berorientasi pada tujuan yang ingin dicapai dengan memanfaatkan alat/instrument yang tersedia. Tujuan mendapatkan keuntungan berlipat dengan cara cepat menyebabkan masyarakat memanfaatkan cukong kayu sebagai perantara untuk menikmati hasil penjualan kayu illegal.

Posisi dari BBKSDA NTT sebagai pengelola kawasan menunjukan posisi negara dengan menegakkan aturan di bidang kehutanan. Masyarakat perambah dan perusak hutan karena menganggap bahwa lahan yang dijadikan lingko adalah hak yang sudah dikuasai turun temurun walaupun ditetapkan sebagai hutan lindung maupun hutan konservasi. Ketika konflik yang terjadi berada pada tahap eskalasi konflik, maka masing-masing pihak yang berkonflik tidak saling mengalah dan menonjolkan serta bertahan pada posisi dan kepentingan yang ditunjukkan dengan tindakan nyata, penggunaan kekerasan dilakukan oleh pihak pengelola kawasan sedangkan dari warga masyarakat mengancam dan mengintimidasi pihak pengelola.

Masing-masing pihak yang berkonflik sebaiknya menurunkan posisi semula yang tadinya tetap mempertahankan posisi masing-masing sehingga posisi cenderung menjadi salah satu harus menang (zero-sum gain) kearah lebih longgar untuk membuka ruang intervensi bagi pihak-pihak luar guna mencari solusi yang win-win.

Pihak-pihak yang berkonflik menyadari bahwa kebutuhan-kebutuhan mereka akan sulit tercapai apabila satu pihak tidak memberi ruang pihak lain memenuhi kebutuhannya. Pihak pengelola kawasan menyadari bahwa kebutuhan agar kawasan kembali berfungsi sesuai peruntukannya sulit terpenuhi apabila kebutuhan lahan dari masyarakat belum terpenuhi. Dari pihak masyarakat menyadari bahwa lahan garapan dalam kawasan tidak mungkin memenuhi kebutuhan mendatang karena kawasan ini adalah kawasan negara yang sewaktu-waktu dapat mengambil tindakan yang lebih keras dari yang telah dilakukan saat ini sehingga masyarakat mulai membuka diri dengan pemerintah dalam upaya penyelesaian konflik.

Pengelolaan TWA Ruteng tidak dapat dilakukan sepihak oleh BBKSDA karena menyalahi hukumhukum alam dalam konteks hutan sebagai satu "sistem" ekologi yang berinteraksi dan saling keterhubungan secara terus menerus dengan "sistem" sosial budaya dan perkembangan ekonomi serta demografi masyarakat di sekitarnya. Di dalam hutan telah terjadi perubahan-perubahan disebabkan oleh faktor alam dan dampak aktivitas manusia atau kombinasi keduanya. Pendekatan dalam mengelola TWA Ruteng seharusnya melalui pendekatan "sistem", yaitu sistem ekologi dan sistem sosial. Dalam sistem sosial perlu kerjasama para pihak kunci yang disebut Tiga Pilar yaitu Unsur Pemerintah, Gereja dan Masyarakat Hukum Adat (TWA Ruteng Menuju Penerapan Kerjasama Berbasis Tiga Pilar (2013:14).

Motto dalam pelaksanaan Tiga Pilar adalah :Mbau Eta Temek Wa (Di Atas hijau, di bawah cukup air) Tela Galang Pe'ang Kete Api One (Di tungku cukup kayu api di atas cukup bahan untuk ditanak). Motto pertama menyatakan kesalingterhubungan antara kelestarian hutan di hulu (kondisinya 
masih baik, hijau) dengan ketercukupan air bagi masyarakat di bawahnya. Air dalam arti luas diartikan sebagai ketercukupan untuk pemenuhan kehidupan masyarakat (sandang, pangan, papan) Motto yang kedua, tentang kerja keras untuk mendapatkan nafkah bagi keluarga. Motto ini dijadikan tujuan pengelolaan TWARuteng: "Hutan Taman Wisata Alam (TWA) Ruteng Lestari, masyarakat di 76 desa rukun-makmur-mandiri dan sejahtera”. Dalam konteks ini, maka manusia sebagai obyek dan sekaligus subyek yang saling mempengaruhi dalam sistem alam dan sistem sosialnya.

Untuk mendorong konsep kelola kawasan dengan pendekatan Tiga Pilar, maka para pihak harus berpegang pada Spirit "3 A", yaitu Ahimsa, Anekanta, dan Aparigraha. Ketiga spirit tersebut adalah : 1) AHIMSA ialah menghentikan semua cara-cara kekerasan, sehingga tidak berlanjut-lanjut dengan adanya orang kehilangan rumah, nyawa atau anggota badan yang tidak mungkin bisa dikembalikan seperti semula, sesudah itu dapat dilakukan langkah-langkah selanjutnya. 2) ANEKANTA ialah melakukan perundingan dan perujukan tanpa menyeragamkan sifat keanekaan yang ada dalam masyarakat. 3) APARIGRAHA ialah kesadaran semua pihak untuk datang berunding sebagai seakan-akan tak punya rumah, tak punya atribut. Artinya dengan kemurnian kalbu, secara bersama-sama merenungkan nilai-nilai universal yang membedakan yang benar dan salah, yang baik dan buruk, yang berfaedah dan tidak berfaidah, serta yang haram dan yang halal.

Ketiga spirit tersebut diharapkan dijadikan suluh, pedoman, dan inspirasi dalam seluruh proses dialog para pihak dalam mendiskusikan berbagai hal, yaitu "persoalan" dan "potensi", baik yang muncul di kawasan TWA Ruteng dan daerah penyangganya. Spirit yang harus selalu dijunjung tinggi dalam melaksanakan konsep Tiga Pilar ini adalah "win-win solution". Bukan, menambah semakin ruwetnya persoalan, tetapi sebaiknya harus diupayakan mencari titik temu atau solusi yang disepakati para pihak dan menguntungkan semua pihak, sesuai dengan kepentingannya masing-masing. (TWA Ruteng Menuju Penerapan Kerjasama Berbasis Tiga Pilar (2013:20).

Musyawarah untuk mencapai mufakat (Sila ke empat Pancasila), harus dijadikan wahana untuk mendapatkan solusi terbaik. Musyawarah dan mufakat diupayakan sebagai cara untuk menyelesaikan masalah dan pengembangan potensi. Hal ini tidak meniadakan pelaksanaan hukum positif (penegakan hukum) bagi para pelanggar kesepakatan, setelah peringatan melalui adat tidak dihiraukan. Maka penerapan hukum positif adalah upaya terakhir yang terpaksa dilakukan oleh pemerintah.

Pilar Pemerintah (BBKSDA, Pemkab dan jajaran dinas terkait) mengadakan pertemuan dilakukan di tingkat Kabupaten dengan mengundang pihak gereja untuk memberikan masukan konstruktif dengan tujuan menyamakan persepsi tentang Tiga Pilar dan dikaitkan dengan tupoksi para pihak ditingkat pemerintah. Pertemuan Pilar Adat ditingkat Gendang menghadirkan tetua adat, Kepala Desa, Paroki dan para tokoh LSM. Tujuan pertemuan ini adalah membangun kesepahaman konsep Tiga Pilar, peran para pihak, bagaimana memulai pekerjaan-membuat skala prioritas kegiatan bersama, membangun pola komunikasi dan koordinasi, siapa melakukan apa, dimana, kapan, mekanisme monev, pembelajaran bersama, dan lain sebagainya. Pada tahap ini, kawasan TWA Ruteng dibagi ke dalam 24 Paroki, setiap Paroki melayani beberapa desa. Wilayah Paroki dan desa di-overlay dengan Wilayah Adat.

Pelaksanaan kegiatan tiga pilar diawali dengan kegiatan pemetaan partisipatif, patroli dan penjagaan kawasan bersama, penanganan kasus-kasus-tumpang tindih wilayah adat dan batas TWA Ruteng, illegal logging, perambahan oleh pihak luar, dsb dan monitoring evaluasi. Pelaksanaan Mubes Masyarakat Desa Perbatasan TWA Ruteng pada tahun 2013 melibatkan para pihak, baik di tingkat kabupaten, provinsi, dan pusat. Tujuan Mubes adalah disepakatinya oleh para pihak (Pemkab dan jajarannya sampai ke tingkat kecamatan dan desa), Gereja/Paroki dan masyarakat adat dalam rangka pengelolaan kolaboratif TWA Ruteng untuk kesejahteraan masyarakat dan pengembangan potensi wisata alam dan jasa lingkungan.

Pada Tanggal 12 Desember 2012 bertempat di Rumah Gendang Induk Colol, Pemkab Manggarai Timur, Kepala Balai Besar KSDA NTT dan jajarannya, Pimpinan DELSOS Ruteng, Direktur LSM Mitra Kita, Direktur LSM Garuda, Direktur Asosiasi Petani Kopi Manggarai (ASNIKOM), Kapolsubsek Mano, Babinsa Mano, dan masyarakat adat Colol, melaksanakan pertemuan dalam nuansa adat 'Lonto Leok' (musyawarah bersama) untuk menyusun rencana dalam rangka pelestarian TWA Ruteng, dan hal-hal yang terkait dengan persoalan yang dihadapi masyarakat hukum adat Colol serta pengembangan potensi TWA Ruteng untuk kepentingan masyarakat. Pertemuan ini menghasilkan kesepakatan bersama 3 pilar yang lebih dikenal dengan 'Kesepakatan 12' sesuai dengan tanggal, bulan dan tahun pelaksanaannya. 
Menghasilkan antara lain 2 (dua) opsi penyelesaian konflik 'tumpang tindih batas' TWA Ruteng di wilayah Colol.

Pada saat itu dihasilkan beberapa Kesepakatan Bersama Tiga Pilar tentang Pelestarian TWA Ruteng yang ditanda tangani oleh para pihak. Adapun poin penting berkaitan dengan hasil kesepakatan tersebut yaitu berupa pilihan dari dua opsi mengenai status lahan/kawasan yang disengketakan. Pilihan tersebut yaitu:

\section{Pilihan 1 : Blok Khusus}

Kebun kopi masyarakat adat Colol diduga tumpang tindih dengan TWA Ruteng sehingga dapat ditetapkan menjadi Blok Khusus sesuai PP No.28 Tahun 2011 dan Permenhut No. P.56/Menhut- II/2006, Tahun 2006). Implikasi hukumnya adalah 1) kawasan tersebut masih merupakan bagian dari TWA Ruteng, 2) dapat dilakukan kegiatan pertanian secara tradisional tanpa ada perluasan ke dalam wilayah hutan, 3) penetapan blok khusus menjadi kewenangan Dirjen Perlindungan Hutan dan konservasi alam atas usulan BBKSDA NTT.

Pilihan 2 : Dikeluarkan

Kebun kopi masyarakat adat Colol diduga tumpang tindih dengan TWA Ruteng dikeluarkan dari dalam kawasan TWA Ruteng. Implikasi hukumnya adalah:

a. Perubahan fungsi kawasan menjadi hutan adat yang diusulkan oleh PEMKAB Manggarai Timur melalui gubernur kepada menteri kehutanan melalui proses revisi tata ruang Kab.Manggarai Timur.

b. Diperlukan waktu lebih dari 2 tahun dan pengawalan prosesnya di tingkat kabupaten, provinsi dan nasional. BBKSDA NTT hanya berwenang memberikan rekomendasi bahwa kawasan tersebut layak secara hukum dengan mempertimbangkan aspek sejarah keberadaan masyarakat adat Colol.

Dalam menentukan pilihan tersebut, maka pada tanggal 18 Maret 2013, dilakukan rapat Tiga Pilar di Aula Paroki Colol. Masyarakat hukum adat Colol memilih pilihan 2 dengan implikasi hukum seperti kesepakatan bersama sedangkan wilayah hutan tetap berfungsi sebagai kawasan hutan TWA Ruteng dan ditetapkan sebagai Blok Tradisional.

Pada wilayah selain Desa adat Colol pada wilayah Pemerintah Daerah Manggarai dan Manggarai Timur selama 3 tahun terakhir berupaya menyelesaikan sengketa dan mencapai kesepakatan mengenai batas antara wilayah adat dan kawasan TWA Ruteng. Penyelesaian konflik di wilayah TWA Ruteng paska diterapkannya kerjasama tiga pilar lebih mengedepankan penyelesaian secara adat. Beberapa kasus pelanggaran hukum kehutanan di TWA Ruteng yang ditangani baik masalah perambahan maupun illegal logging menggunakan denda adat sebagai satu cara penyelesaian masalah secara sosial dan budaya Manggarai. Penyelesaian dengan hukum positif adalah langkah terakhir apabila menemukan jalan buntu.

Dalam kurun waktu 3 tahun sejak Tahun 2013 implementasi tiga pilar terjadi konflik illegal logging dan perambahan di TWA Ruteng sebanyak 12 kasus. Penyelesaian konflik lahan dan penebangan liar terselesaikan dengan hukum adat melalui tiga pilar dengan melibatkan unsur pemerintah, masyarakat adat dan tokoh agama. Penyelesaian konflik sebaiknya dengan cara komunikasi dan pengakuan peran masingmasing pihak. Masyarakat harus menyadari bahwa BKSDA NTT merupakan representasi dari pemerintah yang bertugas melaksanakan dan mengamankan UU dan pihak BBKSDA NTT harus menyadari bahwa masyarakat memiliki norma dan nilai adat.

\section{Simpulan}

Penyebab konflik di lokasi studi yaitu perbedaan sistem nilai yang berimplikasi pada ketidaksepakatan status lahan dan tata batas serta ketidakpastian akses karena persoalan hak dan akses. Konflik hak dan akses menimbulkan tipe konflik terbuka di Kelurahan Waso dan Desa Colol dan konflik laten di Desa Pongkor dan Kelurahan Lempang Paji karena persoalan hak dan akses untuk pemenuhan kebutuhan dasar masyarakat adat. Isu konflik di TWA Ruteng adalah pemantapan kawasan, perambahan kawasan, lemahnya koordinasi antar stakeholder, kesadaran dan ekonomi masyarakat yang rendah serta konflik sosial berkepanjangan. Wujud konflik menurut masyarakat desa hutan mencuat namun tetap ada konflik yang masih tertutup. Fenomena konflik dipengaruhi oleh: hubungan para pihak yang tidak 
harmonis, perbedaan struktural dalam pengambilan keputusan, perbedaan informasi dan referensi yang digunakan serta perbedaan kepentingan antara individu dan organisasi. Dari aspek institusi, penunjukan kawasan TWA Ruteng tidak ditentukan persepsi kolektif sehingga kurang mendapat dukungan para pihak. Peraturan perundangan penetapan taman wisata alam dan implementasinya tidak menjamin kepastian hak dan akses masyarakat adat karena kendala pengetahuan dan pemahaman mengenai peraturan perundangan, keterbatasan sumberdaya serta persoalan administrasi dan birokrasi pembangunan. Konsep tiga pilar di lokasi studi belum optimal karena belum mengurangi laju kerusakan TWA Ruteng dengan masih adanya konflik seperti perambahan dan illegal logging.

\section{Daftar Pustaka}

Bahruni, B., Suhendang, E., Darusman, D., \& Alikodra, H. S. (2007). Pendekatan Sistem Dalam Pendugaan Nilai Ekonomi Total Ekosistem Hutan: Nilai Guna Hasil Hutan Kayu Dan Non Kayu. Jurnal Penelitian Sosial dan Ekonomi Kehutanan, 4(4), 369-380.

Kathalina, D. E. (2008). Legality of national parks and involvement of local people: case studies in Java, Indonesia and Kerala, India. Dissertation. Tsukuba, Japan: The Graduate School of Life and Environmental Sciences, The University of Tsukuba.

Darmanto, D. (2011). Konservasi Global, Taman Nasional dan Praktek Lokal di Pulau Siberut, Sumatera Barat. Jurnal Ilmu Kehutanan, 5(1), 51-65.

Hardin, G. (1968). The tragedy of the commons. Science, 162(3859), 1243-1248.

Iswandono, E. (2016). Integrasi Kearifan Lokal Masyarakat Suku Manggarai Dalam Konservasi Tumbuhan Dan Ekosistem Pegunungan Ruteng Nusa Tenggara Timur. Disertasi. Bogor, Indonesia: Sekolah Pascasarjana Institut Pertanian Bogor.

Iswandono, E., Zuhud, E. A., Hikmat, A., \& Kosmaryandi, N. (2015). Conservation and Human Welfare: A Case Study of The Manggarai Tribe in Ruteng Mountains, Indonesia. International Journal of Sciences: Basic and Applied Research, 24(7), 1-9.

Iswandono, E., Zuhud, E. A. M., Hikmat, A., \& Kosmaryandi, N. (2017). Pengetahuan etnobotani suku Manggarai dan implikasinya terhadap pemanfaatan tumbuhan hutan di Pegunungan Ruteng. Jurnal Ilmu Pertanian Indonesia, 20(3), 171-181.

Kartodihardjo, H. (2013). Kembali ke jalan lurus: kritik penggunaan ilmu dan praktek kehutanan Indonesia. Yogyakarta, Indonesia: Forci Development bekerja sama dengan Tanah Air Beta.

Kriesberg, L., \& Dayton, B. W. (2012). Constructive conflicts: From escalation to resolution. New York, USA: Rowman \& Littlefield Publishers, Inc.

Ostrom, E. (1990). The evolution of institutions for collective action. Cambridge, UK: Cambridge University Press.

Pratiwi, S. (2008). Model pengembangan institusi ekowisata untuk penyelesaian konflik di Taman Nasional Gunung Halimun Salak. Disertasi. Bogor, Indonesia: Sekolah Pascasarjana, Institut Pertanian Bogor.

Sugiyono, S. (2010). Metode Penelitian Administrasi. Bandung, Indonesia: Alfabeta.

Trainor, C., \& Lesmana, D. (2000). Gunung Berapi, Burung-Burung Khas, Tikus Raksasa dan Tenun Ikat yang Menawan: Identifikasi Kawasan-Kawasan Yang Memiliki Arti Penting Bagi Keanekaragaman hayati Global di Flores Nusa Tenggara. Bogor, Indonesia: Direktorat Jendral Perlindungan dan Konservasi Alam/BirdLife International Program/WWF Indonesia, Report No. 11.

Tukan, S. S. (2006). Partisipasi masyarakat dalam pelaksanaan kebijakan publik bidang kehutanan untuk mewujudkan kepemerintahan yang baik di Kabupaten Manggarai. Tesis. Yogyakarta, Indonesia: Magister Hukum Kenegaraan, Universitas Gadjah Mada. 
Wells, M., Bradon, K., \& Hannah, L. (1992). People and parks: linking protected area management with local communities. Washington, D.C., USA: The World Bank/The World Wildlife Fund/U.S. Agency for International Development. 